\title{
THE LOWEST TEMPERATURE IN ANTARCTICA
}

\author{
NINA A. STEPANOVA. \\ Office of Climatology, U.S. Weather Bureau, Washington, D.C. \\ [Manuscript received April 17, 1959]
}

The IGY period 1957-58 was the first time in history that continuous meteorological observations were made in the interior of Antarctica. The U.S. IGY AmundsenScott Station $\left(90^{\circ}\right.$ S., elev. 2,800 m.) and the Soviet IGY stations, Vostok ( $78^{\circ} 27^{\prime}$ S., $106^{\circ} 52^{\prime}$ E., elev. 3,420 m.) and Sovetskaya $\left(78^{\circ} 24^{\prime}\right.$ S., $87^{\circ} 35^{\prime}$ E., elev. $3,570 \mathrm{~m}$.) are located on a high plateau of the Antarctic Continent and the minimum temperatures observed there have set new world records. In fact, the Antarctic winter season of 1958 saw a continuous breaking and resetting of the world minimum temperature record. As it now stands, the $-87.4^{\circ} \mathrm{C} .\left(-125.3^{\circ} \mathrm{F}\right.$.) recorded at Vostok on $A$ ugust 25 is the world record.

Now that this eventful winter is over, the still fragmentary information from Antarctica can be analyzed and summarized. However, a reservation must be made as to the reliability of sources of this information. We are compelled to resort to a practice usually avoided in - scientific analysis; that is, to a utilization of newspaper and radio reports. At this early date these are our only sources for some of the data which may be long in reaching publication in technical journals.

In a previous article [1] on the lowest temperatures reported on earth, we published the then latest record low air temperature for the world. It was $-74.5^{\circ} \mathrm{C}$. $\left(-102.1^{\circ}\right.$ F.) observed at the U.S. Antarctic station at the South Pole (elev. 2,800 m.) on September 17, 1957. This minimum broke the previous record of $-67.7^{\circ} \mathrm{C}$. $\left(-89.9^{\circ}\right.$ F. $)$ observed at Oimekon in eastem Siberia on February 6,1933. Carrying on from where we left off in the previous article, we show in table 1 a chronological list of the later world-record-breaking minima observed in Antarctica during the winter of 1958.

The new record of $-87.4^{\circ} \mathrm{C}$. has exceeded a theoretical estimate of the lowest possible Antarctic temperature made by Shliakhov [2]. His estimate was based on the assumption that radiation balance becomes zero at the theoretical minimum temperature; i.e., the back radiation from the atmosphere equals the upcoming radiation from the surface. Using actual radiation measurements from Vostok 1 and theoretical values derived from soundings made at Vostok 1 in May 1957 and at the South Pole in July 1957, and using the Shekhter radiation nomogram [3], Shliakhov computed the minimum temperature to vary from $-78^{\circ} \pm 2^{\circ} \mathrm{C}$. to $-80^{\circ} \pm 1^{\circ} \mathrm{C}$. He then performed another calculation based on greater station elevation $\left(5 \mathrm{~km}\right.$. m.s.l.) and using a mean lapse rate of $5^{\circ} \mathrm{C}$. per $1,000 \mathrm{~m}$. above the inversion layer as determined from radiosoundings made at the interior stations. $\mathrm{He}$ assumed the temperature of the snow surface to be $-75^{\circ} \mathrm{C}$., the strength of the inversion $-30^{\circ} \mathrm{C}$., the depth of the inversion layer $1 \mathrm{~km}$., and also assumed that

TARLE 1.-Temperature minima observed in Antarctica since 1957

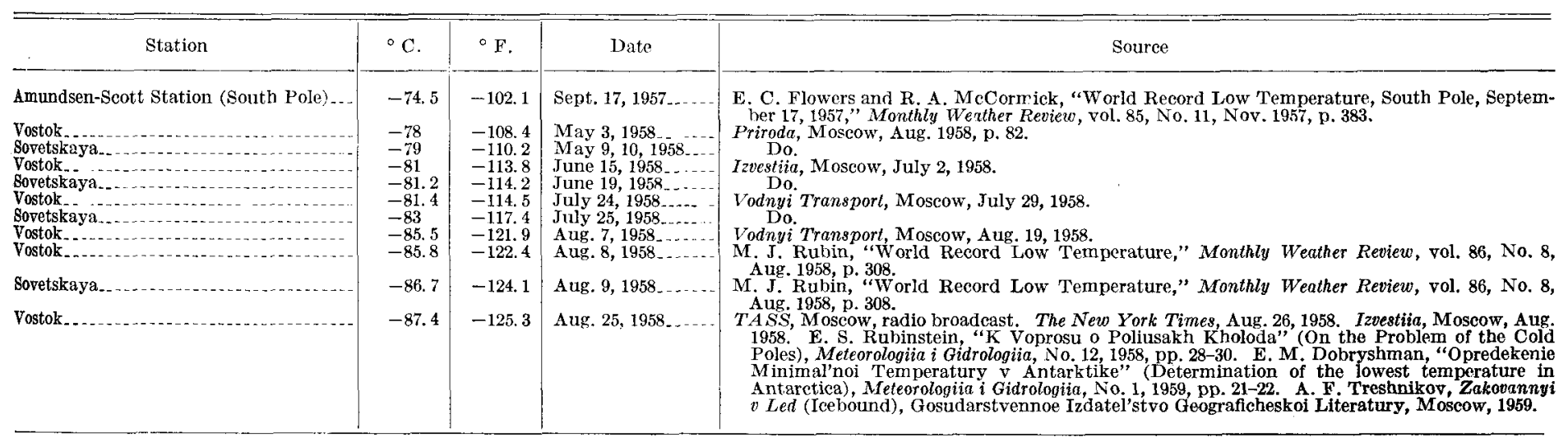


the air was saturated in all layers. Calculating the back radiation of the atmosphere $\left(E^{\prime}\right)$ from the Shekhter radiation nomogram and the corresponding equilibrium temperature $\left(T_{0}\right)$, he found: $E^{\prime}=0.100 \pm 0.005 \mathrm{cal} . / \mathrm{cm} .{ }^{2} /$ min., and $T_{0}=-85^{\circ} \pm 2^{\circ} \mathrm{C}$. at $5 \mathrm{~km}$. above sea level. Taking into account the above estimated lapse rate, Shliakhov came to the conclusion that, at the height of about $4 \mathrm{~km}$., in Antarctica the lowest temperature could not be below $-80^{\circ} \pm 2^{\circ} \mathrm{C}$. At higher levels it could be lower by $0.5^{\circ}$ per $100 \mathrm{~m}$.

The early low minima of May and June 1958 seemed to bear out this calculation, but the final record was $5.4^{\circ}$ lower than the predicted limit. In the following note, Dr. Wexler attempts to explain why the theoretical minimum temperature was too high.

\section{REFERENCES}

1. Nina A. Stepanova, "On the Lowest Temperatures on Earth," Monthly Weather Review, vol. 86, No. 1, Jan. 1958, p. 6-10.

2. V. I. Shliakhov, "O Minimal'nykh 'Temperaturakh v Antarktide" (On Minimum Temperatures in Antaretica), Meteorologia $i$ Gidrologiia, No. 4, 1958, pp. 5-7.

3. F. M. Shekhter, "O Vychislenii Radiatsionnogo Teplovogo Potoka $v$ Atmosfere" (On Calculations of the Radiational Heat Flux in the Atmosphere), Trudy, Glavnaia Geofizicheskaia Observatoria, vol. 22,1950, p. 84. 